\title{
Correction to: Jurisdiction shopping and foreign location choice: The role of market and nonmarket experience in the European solar energy industry
}

Panikos Georgallis ${ }^{1}$, João Albino-Pimentel ${ }^{2}$ and Nina Kondratenko ${ }^{3}$

\footnotetext{
${ }^{1}$ Amsterdam Business School, University of Amsterdam, M.217 Plantage Muidergracht 12, 1018 TV Amsterdam, The Netherlands; ${ }^{2}$ Copenhagen Business School, Kilevej 14a, 2000 Frederiksberg, Denmark; ${ }^{3}$ Darla Moore School of Business, University of South Carolina, 1014 Greene Street, Columbia, SC 29208, USA

Correspondence:

J Albino-Pimentel, Copenhagen Business School, Kilevej 14a, 2000 Frederiksberg, Denmark e-mail: ja.si@cbs.dk
}

Journal of International Business Studies (2021) 52, 878.

https://doi.org/ | 0.1057/s4 | 267-020-00363-5

\section{Correction to: \\ Journal of International Business Studies (2020) https://doi.org/10.1057/s41267-020-00358-2}

The original version of this paper was inadvertently published with errors in the author names. The correct author names are Panikos Georgallis, João Albino-Pimentel and Nina Kondratenko.

The original article has been corrected. We apologise for any inconvenience caused to our readers.

Publisher's Note Springer Nature remains neutral with regard to jurisdictional claims in published maps and institutional affiliations. 